\title{
Spinal Arachnoid Cysts Associated with Syringomyelia: A Review of the Literature and Report of a Case
}

\author{
Syringomyeli ile Illişkili Spinal Araknoid Kist: Literatürün Gözden \\ Geçirilmesi ve Bir Olgu Sunumu
}

\author{
Bulent TUCER ${ }^{1}$, Muhammet Bahadır YILMAZ², Mehmet Ali EKICI ${ }^{3}$, Ahmet MENKU¹, Kemal KOC \\ ${ }^{1}$ Erciyes University, School of Medicine, Department of Neurosurgery, Kayseri, Turkey \\ ${ }^{2}$ Ministry of Health, Training and Research Hospital, Department of Neurosurgery, Kayseri, Turkey \\ ${ }_{3}^{3}$ Ministry of Health, Training and Research Hospital, Department of Neurosurgery, Bursa, Turkey
}

Corresponding Author: Muhammet Bahadır YILMAZ / E-mail: mbahadiryilmaz@yahoo.com.tr

\begin{abstract}
Syringomyelia is a not infrequent pathology that develops related to changes in cerebrospinal fluid dynamics due to many etiological factors. The development of syringomyelia through a spinal arachnoid cyst is quite rare and has been defined in only 31 cases in the literature. A case due to thoracic epidural lipomatosis has also been reported. There have been no previous reports of thoracic region epidural lipomatosis with underlying arachnoid cyst and syringomyelia as in our case. We present a 27-year-old patient who developed thoracic arachnoid cyst and underlying syringomyelia because of the pressure of the thoracic epidural fat tissue and also evaluate the characteristics of patients with syringomyelia by virtue of an arachnoid cyst previously reported in the literature.
\end{abstract}

KEYWORDS: Epidural lipomatosis, Spinal arachnoid cyst, Syringomyelia, Surgical treatment

öz

Siringomyeli, birçok etiyolojik faktörden kaynaklanan serebrospinal sıvı dinamiğindeki değişikliklerle ilgili olarak gelişen, nadir olmayan bir patolojidir. Spinal araknoid kistin sebep olduğu siringomyeli gelişimi oldukça nadirdir ve literatürde yalnızca 31 olguda tanımlanmıştır. Ayrıca torakal epidural lipomatozisten kaynaklanan olgu da rapor edilmiştir. Bizim olgumuzdaki gibi torakal bölge epidural lipomatozis ile altında yatan araknoid kist ve siringomyeli daha önce rapor edilmemiştir. Biz, torakal epidural yağ basısından dolayı torakal araknoid kist ve altında yatan siringomyelisi olan 27 yaşında bir hasta sunuyoruz. Ayrıca daha önce literatürde rapor edilmiş araknoid kist nedeniyle oluşan siringomyelili hastaların özelliklerini değerlendiriyoruz.

ANAHTAR SÖZCÜKLER: Epidural lipomatozis, Spinal araknoid kist, Siringomyeli, Cerrahi tedavi

\section{INTRODUCTION}

Syringomyelia is a dilatation caused by excessive cerebrospinal fluid (CSF) accumulation within the central canal or the extracanalicular area. Type 1 and 2 Chiari, the Dandy-Walker syndrome, cerebellar ectopia, basilar impression, basilar arachnoiditis, posterior fossa tumors and arachnoid cysts, medulla spinalis tumors, spinal trauma and infections are among the pathologies that can cause syringomyelia. There are also several idiopathic cases. Syringomyelia that occurs due to spinal arachnoid cysts has first been reported in 1973, followed by another 30 other cases until now (20). Excluding the cases at the craniocervical junction, most spinal arachnoid cysts that cause syringomyelia are located in the thoracic region. A syrinx case due to thoracic epidural lipomatosis has been defined in one patient while there are no previous reports of a case with epidural lipoma and an underlying arachnoid cyst and syringomyelia. We present a hitherto unreported case and also evaluate the features of the 31 previously published cases.

\section{CASE REPORT}

A 27-year-old male presented with weakness and contractions in the legs for approximately 3 years. The neurological examination revealed two-point discrimination of $4 \mathrm{~cm}$ at the the $\mathrm{L} 1$ dermatome, hyperactive patellar and Achilles reflexes in the lower extremity, and a wide gait. The investigations showed an extramedullary mass between the 7 th cervical and 5 th thoracic vertebra and syringomyelia between the 6th and 9th thoracic vertebra (Figure 1A-D). Surgery was planned. Bilateral 3rd to 6th thoracic vertebrae laminae were removed with the power drill for laminoplasty. Magnetic resonance imaging (MRI) revealed an epidural fat tissue that was much thicker than normal and extended from the midline towards the right in a location indicating an extramedullary mass. Once the mass was excised, intraoperative ultrasonography 
(USG) showed the localization of the lesion within the dura (Figure 1A-D). The lesion was seen to be an arachnoid cyst when the dura was opened (Figure 1A-D). The posterior wall of the cyst was excised. There was marked compression of the spinal cord under the cyst (Figure 2A, B). In the postoperative early period, there was significant improvement in the patient's gait and the contractions in the legs decreased. The postoperative 2-month radiological follow-up showed partial recovery of the syringomyelia (Figure $3 A-D$ ). The patient is being followed-up from the neurological and radiological aspects.
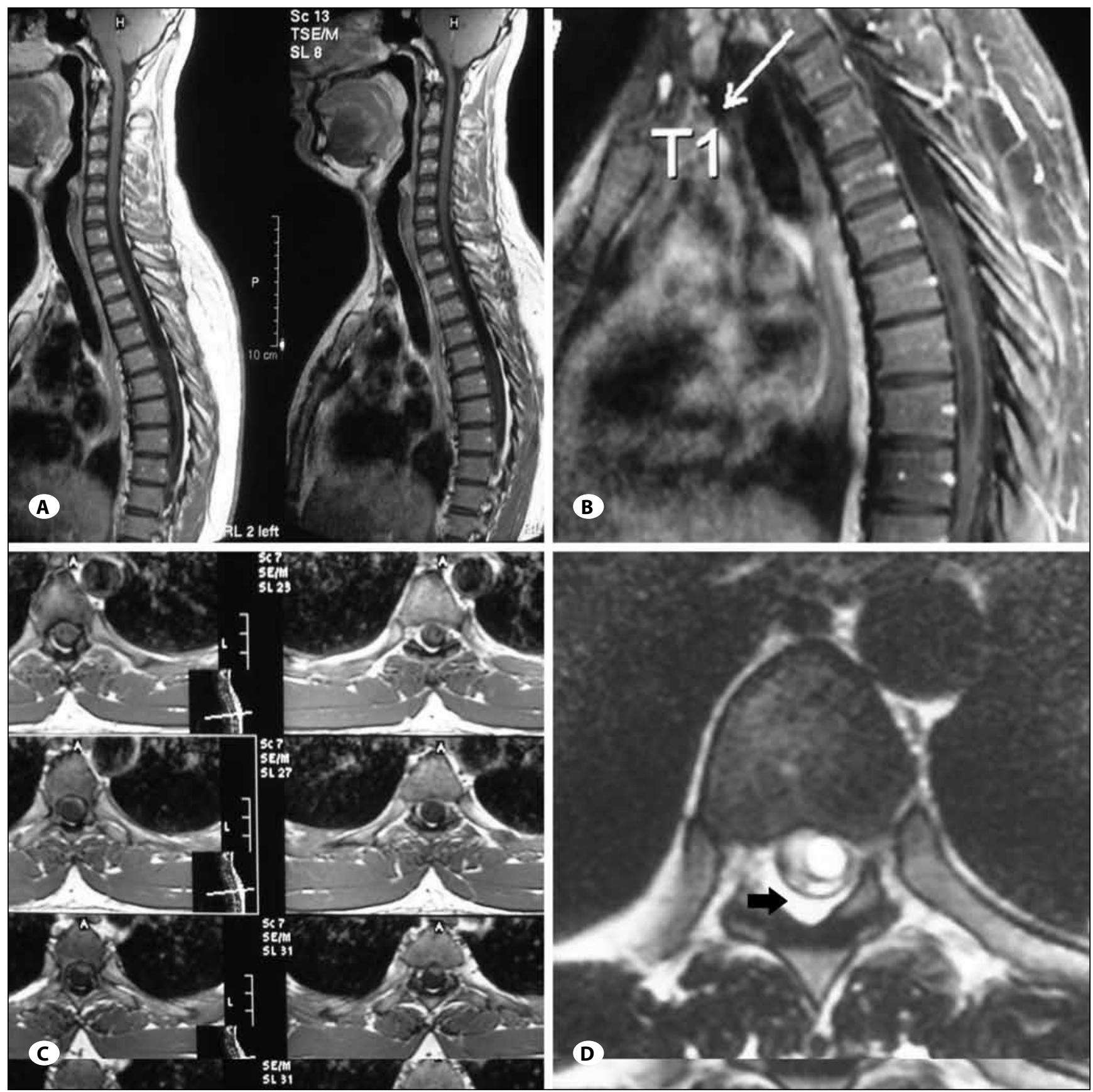

Figure 1: A, B) T1-weighted sagittal MRI images show a hypointense lesion with extramedullary location between the 7th cervical vertebra and 5th thoracic vertebra, and syringomyelia together with hyperintense fat tissue that is much thicker than normal between the 6th and 9th thoracic vertebrae. C, D) Axial T1- and T2-weighted images show an appearance consistent with fat tissue (arrow) of abnormal thickness in the spinal cord posterior and right posterolateral areas together with arachnoid cyst and syringomyelia. 


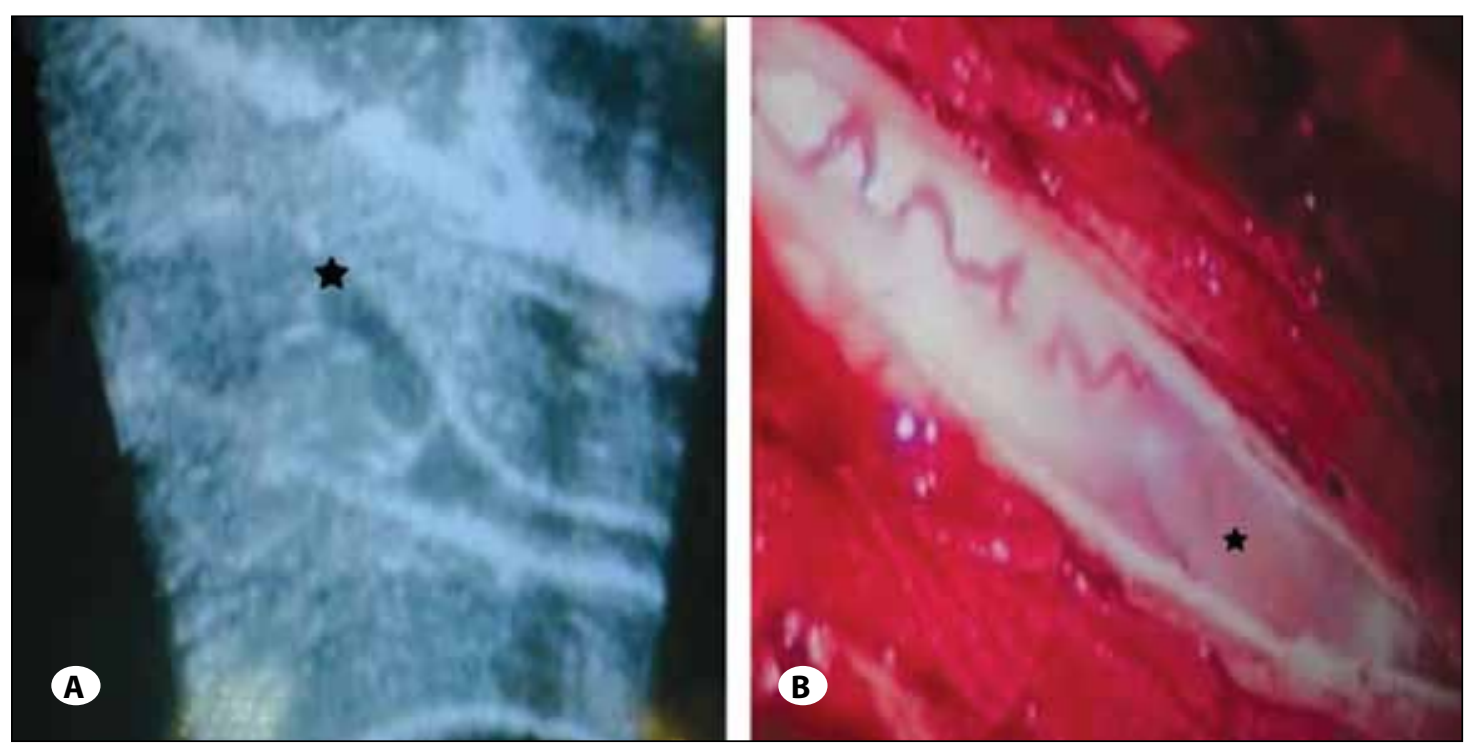

Figure 2:

A) Intraoperative USG shows an appearance consistent with an arachnoid cyst compressing the cord (asterisk).

B) The arachnoid cyst is seen below after the dura is opened at the midline (asterisk).
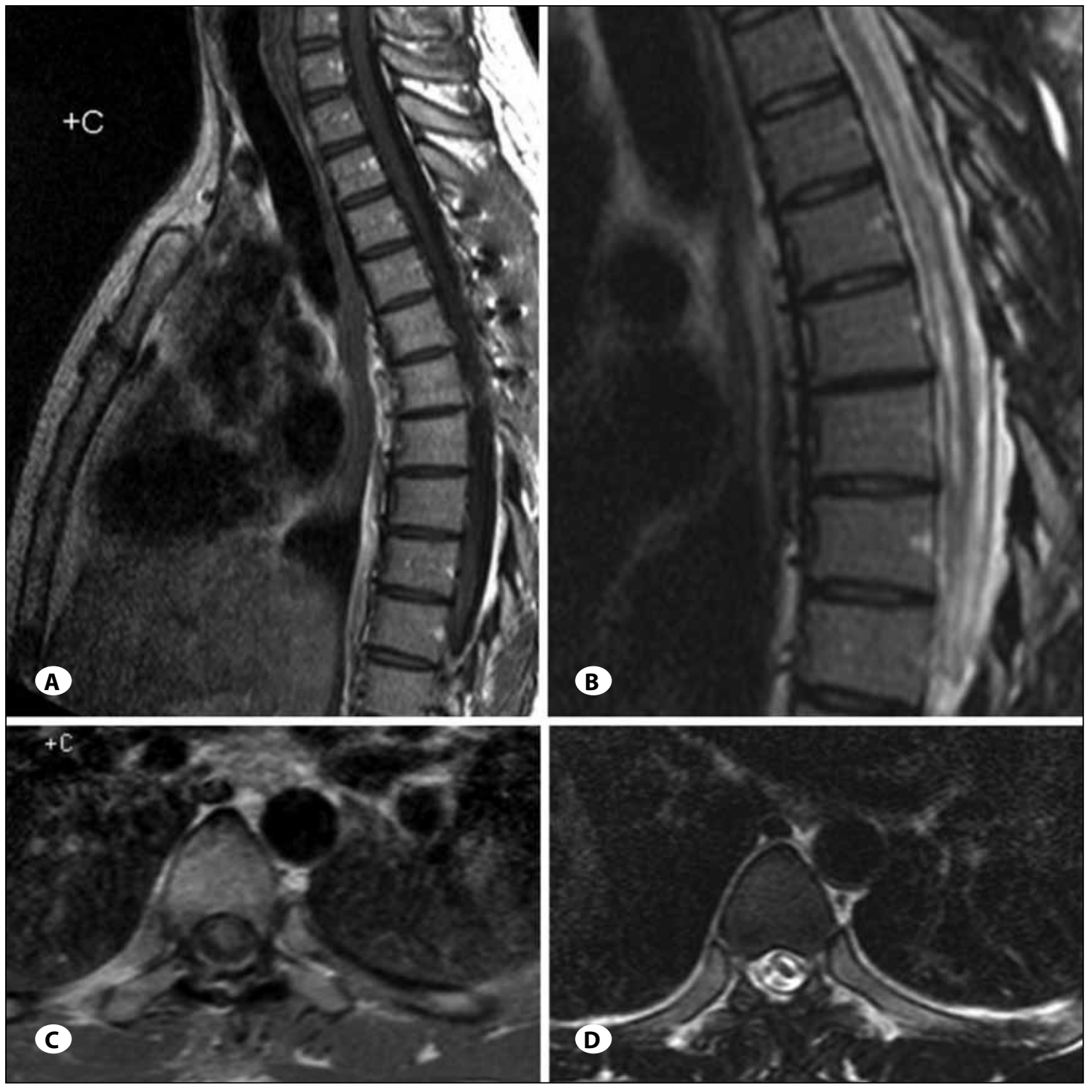

Figure 3:

A,B) Sagittal

$\mathrm{T} 1-\mathrm{T} 2$ and

C,D) axial T1-

T2 weighted

MRI images

show partial recovery of the syringomyelia and successful resection of the cyst at postoperative. 


\section{DISCUSSION}

Causes of syringomyelia include craniocervical junction pathologies (Type 1 and 2 Chiari malformation, basilar impression), posterior fossa tumors and cysts, the DandyWalker syndrome, cerebellar ectopia, basilar arachnoiditis, infections, spinal trauma, spinal tumors and idiopathic cases $(9,13,31)$. Syringomyelia caused by posterior fossa or craniosacral junction tumor and arachnoidal cysts has been reported in many articles. Syringomyelia due to a spinal arachnoid cyst is quite rare and there is no information regarding its incidence. A total of 31 cases have been reported so far $(1,4,7-9,13,18,20,24,26,31,32,34,35)$. An arachnoid cyst of thoracic localization is reported most commonly but other localizations are also present.

Syringomyelia may also cause sensory and motor deficit, first motor neuron findings, urinary and fecal incontinence, painless arthropathy, and pain in the neck, back, and occipital region. Spinal arachnoidal cysts are usually asymptomatic but are now being found more frequently thanks to radiological developments. They may cause pain in the back and chest, sensory and motor disturbances due to spinal cord pressure, radicular symptoms, urinary and fecal incontinence, and first motor neuron findings $(23,31)$.

There is no theory that fully explains syringomyelia or spinal arachnoid cyst development at present. The common view is that syringomyelia is caused by changes in cerebrospinal fluid dynamics $(9,13)$. Spinal arachnoid cysts could be a congenital condition but are more probably multifactorial. It is said that the possibly congenital cases are caused by arachnoid herniation with hydrostatic pressure from a dural defect while cases that are not congenital may be due to previous surgery, subarachnoid bleeding, infection or a trauma $(8,9)$. The septum posticum diverticule theory of Perret et al. (25) can explain posterior arachnoid cysts but not those with an anterior localization. Our case had epidural fat tissue that was much thicker then normal and compressed the dura, at a localization adjacent to the arachnoid cyst. It is possible that this tissue gradually caused a disturbance of the CSF circulation in the subarachnoid region and than contributed to syrinx formation with an expanding arachnoid cyst.

Milhorat et al. (21) have classified syringomyelia into 3 groups according to autopsy findings and clinical and neuropathological features in their study where they evaluated 105 postmortem cases with syringomyelia not due to tumor. They found central canal dilation associated with the 4th ventricle (communicating) in 47 , central canal dilation (isolated-non communicating) not associated with the 4th ventricle in 23 , and a syrinx that was extracanalicular within the parenchyme in 35 of the 105 patients. Atrophic or neoplastic cavitations may also be seen in addition to these 3 categories $(13,21)$. The communicating type has a cavity that is partially or totally surrounded by ependyme, with a size that depends on the stenosis duration. The article emphasized that noncommunicating central canal dilation is associated with spinal arachnoiditis, cervical spinal stenosis, basilar impression, and the Chiari type 1 that affect CSF dynamics (13, 21). The extracanalicular type is seen in conditions that cause spinal cord injury such as hemorrhage, infarct and trauma. Samii et al. (28) have reported the presence of a syrinx at the high rate such of $45 \%$ in 100 patients with intramedullary tumor. They have postulated that changes in the cerebrospinal and extracellular fluid due to the intramedullary tumor may cause syrinx development (28). Takeuchi et al. (31) have reported that large arachnoid cysts change cerebrospinal and extracellular fluid flow by causing spinal compression and might therefore cause syringomyelia.

Cases of arachnoid cyst and syringomyelia development after tuberculosis meningitis have been reported $(9,17,33)$. Huang et al. (9) have also reported syringomyelia due to a small arachnoid cyst located in the posterior fossa in patients with a previous history of tuberculous meningitis. The same article mentions 2 patients with spinal cord compression and syringomyelia due to a foramen magnum lesion. The first patient with a type 1 Chiari malformation had compression of the spinal cord at the foramen magnum by the cerebellar tonsils causing syringomyelia while the second patient showed the same pathology due a posterior fossa lesion pushing the cerebellar tonsils downward (9). Bhatoe et al. (2) have reported 1 patient due to tentorial meningioma, Klekamp et al. (15) 3 patients with a posterior fossa mass, Muzumdar et al. (22) and Wu et al. (36) one patient each with cerebellar pilocytic astrocytoma, El Hassani et al. (5) a patient with medulloblastoma of the cerebellar vermis, and Suyama et al. (29) a patient with a cerebellar dermoid tumor. All these patients suffered from syringomyelia associated with tonsillar herniation secondary to a posterior fossa lesion (9). Tachibana et al. (30), evaluated 164 patients with a posterior fossa lesion and found 24 had tonsil herniations of which 5 developed syringomyelia. Not only tumors but arachnoid cysts of the posterior fossa and Dandy-Walker syndrome can cause the same problem $(6,12,19,27)$.

An arachnoid cyst in the foramen magnum due to direct spinal cord compression instead of arachnoid cysts that show spinal cord compression due to tonsillar herniation is quite rare (9). Jain et al. (10) and Kiran et al. (14) have reported giant posterior fossa arachnoid cysts that have extended to the spinal cord and caused syringomyelia. The 3rd case reported by Huang et al. (9) is a cyst that was small but extended from foramen magnum to the atlas level.

In addition to all these causes of syringomyelia, there have been 31 reported cases due to a pure spinal arachnoid cyst (Table I). The first was by McLean et al. who reported a 33-year-old male patient with sensory deficit in the arms and chest and shoulder pain in 1973 (20). The patient had syringomyelia from the foramen magnum to thoracic 3 and an arachnoid cyst at thoracic 3-4. Arachnoid cyst excision and syringomyelia fenestration lead to neurological improvement in the patient. The largest series are the 8 cases reported by Holly et al. (8), and the 5 cases reported by Andrews et al. (1). The data of the cases presented in Table I shows that the 


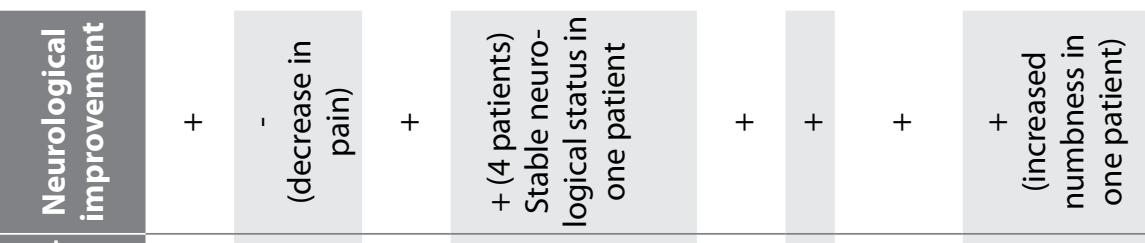

\begin{tabular}{|c|c|c|c|c|c|c|c|c|c|c|c|c|c|c|}
\hline 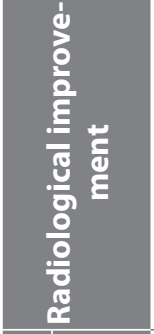 & $\sim$. & $\sim$. & $\sim$. & 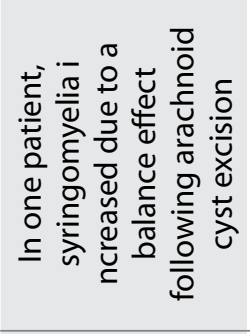 & + & + & + & + & + & ' & + & ' & + & + \\
\hline$\frac{\frac{5}{0}}{8}$ & 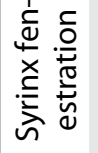 & ' & ' & 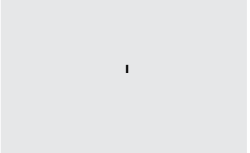 & ' & ' & ' & ' & ' & I & ' & ' & ' & ' \\
\hline 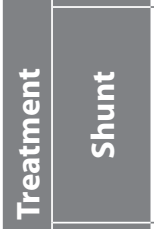 & ' & ' & 1 & 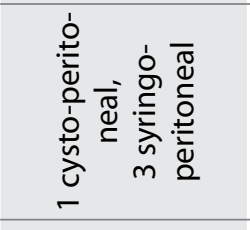 & ' & ' & ' & 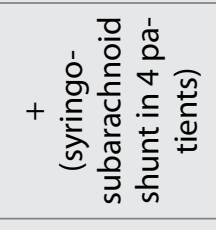 & ' & & ' & 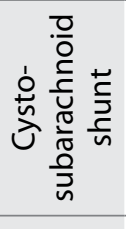 & & ' \\
\hline 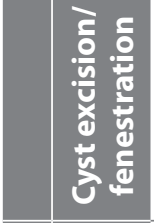 & + & + & + & 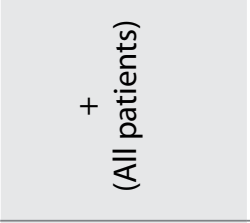 & + & + & + & 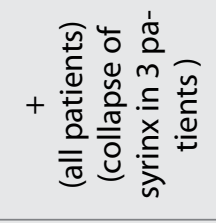 & + & 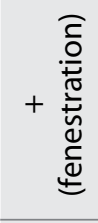 & + & 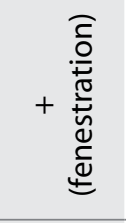 & + & + \\
\hline 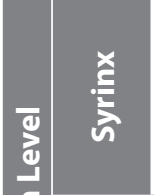 & 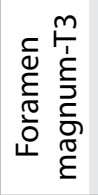 & $\begin{array}{l}\infty \\
1 \\
上\end{array}$ & $\stackrel{\sim}{\mathfrak{n}}$ & 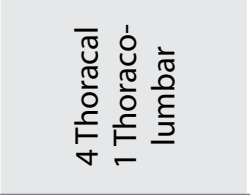 & 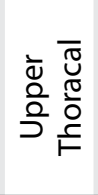 & $\begin{array}{l}a \\
b \\
\bullet\end{array}$ & 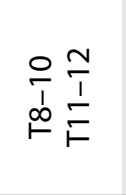 & 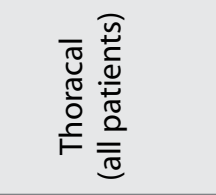 & 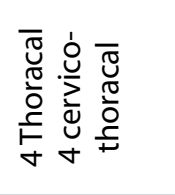 & 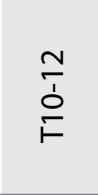 & 皇 & $\frac{⿱ 亠}{\dot{U}}$ & $\begin{array}{l}\text { 음 } \\
\text { 응 } \\
\text { 오 }\end{array}$ & $\begin{array}{l}\stackrel{\circ}{\emptyset} \\
\stackrel{b}{\circ}\end{array}$ \\
\hline 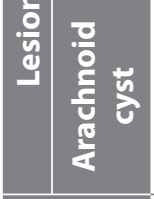 & $\stackrel{+}{\stackrel{+}{\rho}}$ & $F$ & $\begin{array}{l}p \\
1 \\
m \\
r\end{array}$ & 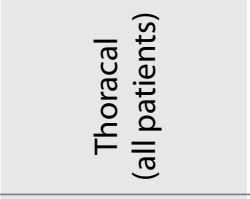 & 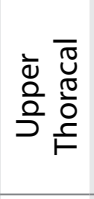 & $\bullet$ & $\begin{array}{l}\infty \overline{1} \\
1 \\
\stackrel{1}{p}\end{array}$ & 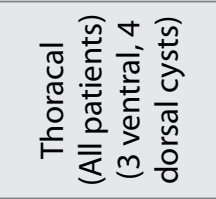 & 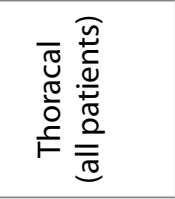 & $\overline{\bar{g}}$ & $\stackrel{m}{\stackrel{n}{i}}$ & 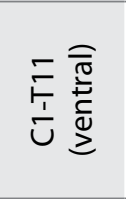 & $\stackrel{+}{\sim}$ & $\frac{\stackrel{n}{\frac{1}{1}}}{\mathrm{O}}$ \\
\hline 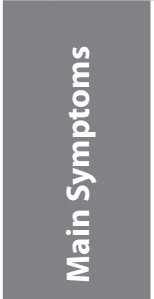 & 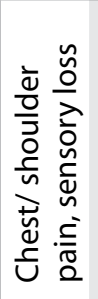 & 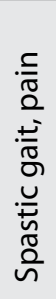 & 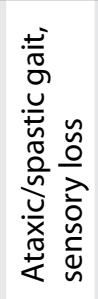 & 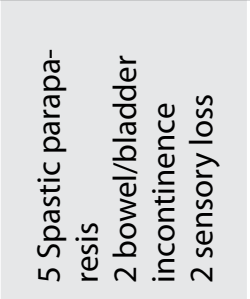 & 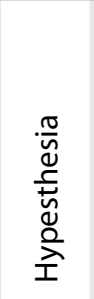 & 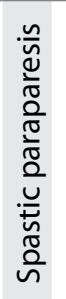 & 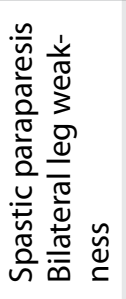 & 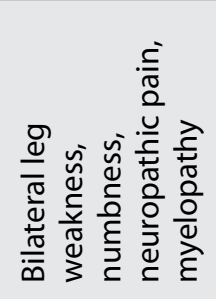 & 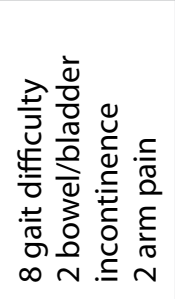 & 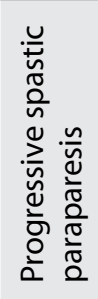 & 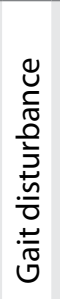 & 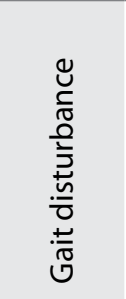 & 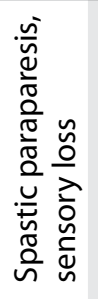 & 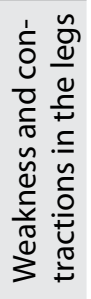 \\
\hline 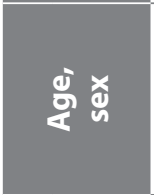 & $\sum_{m}^{j}$ & $\sum_{m}^{j}$ & $\sum_{\substack{n \\
n}}$ & 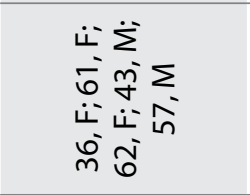 & $\sum_{i}$ & $\begin{array}{l} \\
\text { in }\end{array}$ & 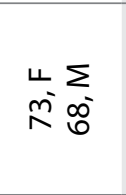 & 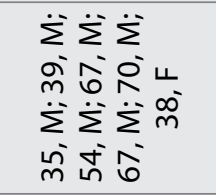 & 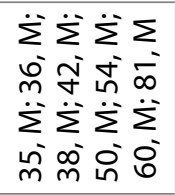 & $\sum_{i}$ & 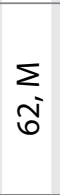 & $\sum_{\text {in }}$ & $\sum_{n}^{-}$ & 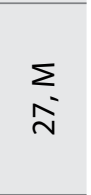 \\
\hline 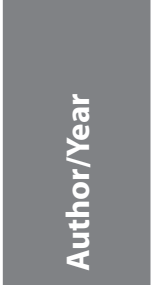 & 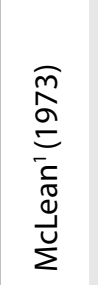 & 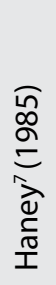 & 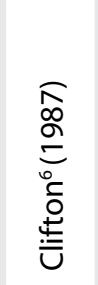 & 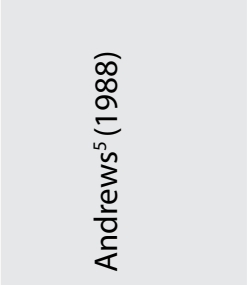 & 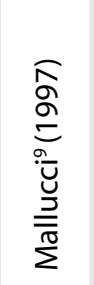 & 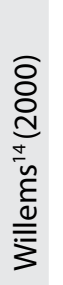 & 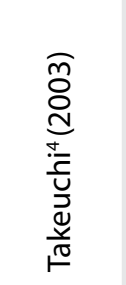 & 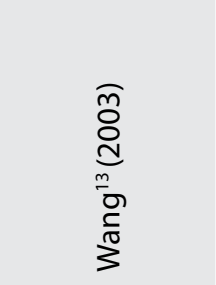 & 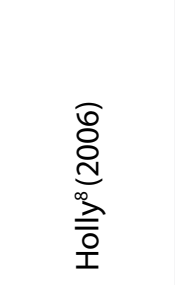 & 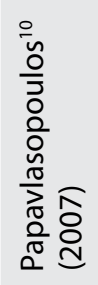 & $\begin{array}{l}\text { ò } \\
\text { ò } \\
\text { me } \\
\text { है }\end{array}$ & 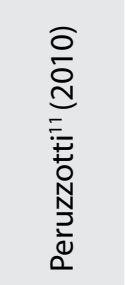 & 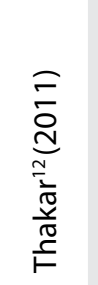 & 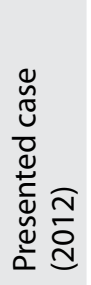 \\
\hline
\end{tabular}


mean age of the 32 patients with 25 males (78.1\%) and 7 females $(21.9 \%)$ was $48.3(15-81)$ years. The patients usually presented with difficulty walking due to spastic paraparesis of the lower extremity and urinary and fecal incontinence. Most of the symptoms were long term. 4 patients had an anterior (12.5\%) and 28 patients a posterior (87.5\%) arachnoid cyst. Wang et al. reported that ventral arachnoid cysts generally cause weakness and artery compression while those with a dorsal location more frequently lead to neuropathic pain and numbness (34). The arachnoid cyst was located in the thoracic region (84.4\%) in 27 patients, cervicothoracic region in 3 patients (9.4\%), thoracolumbar region in 1 patient (3.1\%), and the sacral region in 1 patient (3.1\%). We see that lower extremity weakness and problems with walking are more common, consistent with the thoracic region predominance of the lesions. The syringomyelia was at a higher level than the arachnoid cyst in 9 patients and at the same or a lower level in the other patients. Arachnoid cyst excision or fenestration for treatment had a high degree of effectiveness. All patients underwent arachnoid cyst wall excision or fenestration but 1 patient required syringomyelia fenestration, and 3 patients syringoperitoneal shunt, 1 cystoperitoneal shunt, 1 cystosubarachnoid shunt and 4 syringosubarachnoid shunt placement. The success rate increased markedly with these additional treatments. There are no MR results for the 3 cases before 1987 but radiological improvement was obtained in 26 of the 29 other patients (89.7\%). A meaningful neurological recovery was seen in 28 of 32 patients (87.5\%). We achieved early postoperative neurological and radiological improvement in our presented case with basic cyst wall excision. The patient was followedup from the radiological and neurological aspects. When we look at cases where radiological and neurological success was not achieved, one had an anterior giant arachnoid cyst and the other had significant leptomeningeal calcification that prevented adequate decompression. Andrews et al. presented a patient where syringomyelia increased due to a balance effect following arachnoid cyst excision, and a syringoperitoneal shunt placement was required (1).

The only spinal epidural lipomatosis case related to a syrinx in the literature has been reported by Citow et al. in 2000 (3). The 54-year-old male patient complained of progressive lower extremity weakness for the last 15 years together with urinary and fecal incontinence, and thoracic MR showed epidural lipomatosis at thoracic 1-10 and syringomyelia at thoracic 1-3 (3). The patient was not obese and there was no history of steroid usage. The lipoma was excised after laminectomy and the patient showed both clinical and radiological recovery. Our case had syringomyelia and epidural fat mass together with an arachnoid cyst at the same localization. There were none of the conditions that cause steroid levels to increase and therefore lead to spinal epidural lipomatosis such as morbid obesity, Cushing's disease or external steroid intake. We believe that the epidural fat mass that was much thicker than normal in our case caused compression and disturbed CSF flow in the arachnoid space, leading to arachnoid cyst development by trapping the fluid that later enlarged and caused syringomyelia. Our case with concurrence of syringomyelia, arachnoid cyst and spinal epidural lipoma is the first to be reported in the literature.

\section{CONCLUSION}

In conclusion, the number of spinal arachnoid cysts detected and syringomyelial cases presented has increased with developments in MRI. An increase in the number of cases in the future will lead to better evaluation of the percentage of arachnoid cysts as a cause of syringomyelia and also of the rates of radiological and neurological recovery with different treatment options. In light of the presented cases, it is obvious that even single wall excision can lead to satisfactory results in syringomyelia due to spinal arachnoid cysts. Adequate spinal cord decompression and arachnoid cyst excision can lead to recovery to a large extent and obviate the need for syrinxrelated treatment $(9,26,36)$. The use of a cystoperitoneal or cystoatrial shunt, syringomyelia fenestration or shunt placement can increase the success rate when an adequate result has not been obtained otherwise $(9,11,16,31)$.

\section{REFERENCES}

1. Andrews BT: Intradural arachnoid cysts of the spinal cord associated with intramedullary cysts. J Neurosurg 68: 544-549, 1988

2. Bhatoe HS: Tonsillar herniation and syringomyelia secondary to a posterior fossa tumour. Br J Neurosurg 18: 70-71, 2004

3. Citow JS, Kranzler: Thoracic epidural lipomatosis with associated syrinx: Case report. Surg Neurol 53(6):589-591, 2000

4. Clifton AG: Idiopathic spinal arachnoid cyst and syringomyelia: Case report. Br J Radiol 60: 1023-1025, 1987

5. El Hassani Y, Burkhardt K, Delavellle J, Vargas MI, Boex C, Rilliet B: Symptomatic syringomyelia occurring as a late complication of posterior fossa medulloblastoma removal in infancy in a boy also suffering from scaphocephaly. Childs Nerv Syst 25: 1633-1637, 2009

6. Galarza M, López-Guerrero AL, Martínez-Lage JF: Posterior fossa arachnoid cysts and cerebellar tonsillar descent: Short review. Neurosurg Rev 33: 305-314, 2010

7. Haney A: Association of post traumatic spinal arachnoid cyst and syringomyelia. J Comput Tomogr 9: 137-140, 1985

8. Holly LT, Batzdorf U : Syringomyelia associated with intradural arachnoid cysts. J Neurosurg Spine 5(2): 111-116, 2006

9. Huang $\mathrm{H}, \mathrm{Li}$ Y, Xu K, Li Y, Qu L, Yu J: Foramen magnum arachnoid cyst induces compression of the spinal cord and syringomyelia: Case report and literature review. Int J Med Sci 8(4): 345-350, 2011

10. Jain R, Sawlani V, Phadke R, Kumar R: Retrocerebellar arachnoid cyst with syringomyelia: A case report. Neurol India 48: 81-83, 2000

11. Jensen F: Recurrent intraspinal arachnoid cyst treated with a shunt procedure. Acta Neurochir 39:127-129, 1977

12. Kasliwal MK, Suri A, Sharma BS: Dandy Walker malformation associated with syringomyelia. Clin Neurol Neurosurg 110(3): 317-319, 2008 
13. Kim MS, Kim SH: Syringomyelia associated with a spinal arachnoid cyst. J Korean Neurosurg Soc 45(5): 315-317, 2009

14. Kiran NA, Kasliwal MK, Suri A, Mahapatra AK: Giant posterior fossa arachnoid cyst associated with syringomyelia. Clin Neurol Neurosurg 112: 454-455, 2010

15. Klekamp J, Samii M, Tatagiba M, Sepehrnia A: Syringomyelia in association with tumours of the posterior fossa. Pathophysiological considerations, based on observations on three related cases. Acta Neurochir (Wien) 137: 38-43, 1995

16. Lange $M$, Oeckler R: Results of surgical treatment in patients with arachnoid cysts. Acta Neurochir (Wien) 87(3-4): 99-104, 1987

17. Lolge S, Chawla A, Shah J, Patkar D, Seth M: MRI of spinal intradural arachnoid cyst formation following tuberculous meningitis. Br J Radiol 77: 681-684, 2004

18. Mallucci CL: Idiopathic syringomyelia and the importance of occult arachnoid webs, pouches and cysts. Br J Neurosurg 11: 306-309, 1997

19. Marin SA, Skinner CR, Da Silva VF: Posterior fossa arachnoid cyst associated with Chiari I and syringomyelia. Can J Neurol Sci 37: 273-275, 2010

20. McLean DR: Posttraumatic syringomyelia. Neurosurgery 39: 485-492, 1973

21. Milhorat TH, Capocelli AL Jr, Anzil AP, Kotzen RM, Milhorat RH: Pathological basis of spinal cord cavitation in syringomyelia: Analysis of 105 autopsy cases. J Neurosurg 82(5): 802-812, 1995

22. Muzumdar D, Ventureyra EC: Tonsillar herniation and cervical syringomyelia in association with posterior fossa tumors in children: A case-based update. Childs Nerv Syst 22: 454-459, 2006

23. Palmer JJ: Spinal arachnoid cysts: report of six cases. J Neurosurg 41: 728-735, 1974

24. Papavlasopoulos F, Stranjalis G, Kouyialis AT, Korfias S, Sakas D: Arachnoiditis ossificans with progressive syringomyelia and spinal arachnoid cyst. J Clin Neurosci 14(6):572-576, 2007
25. Perret G, Green D, Keller J: Diagnosis and treatment of intradural arachnoid cysts of the thoracic spine. Radiology 79: 425-429, 1962

26. Peruzzotti-Jametti L, Ferrari S, Politi LS, Snider S, Mammi S, Comi G, Comola M: Giant anterior arachnoid cyst associated with syringomyelia: Implications for treatment and follow-up. Spine (Phila Pa 1976) 35(8): 322-324, 2010

27. Richter EO, Pincus DW: Development of syringohydromyelia associated with Dandy-Walker malformation: Treatment with cystoperitoneal shunt placement. Case report. J Neurosurg 104: 206-209, 2006

28. Samii M: Surgical results of 100 intramedullary tumors in relation to accompanying syringomyelia. Neurosurgery 35 : 865-873, 1994

29. Suyama K, Ujifuku K, Hirao T, Takahata $H$, Ito $M$, Yonekura M, Nagata I: Symptomatic syringomyelia associated with a dermoid tumor in the posterior fossa. Neurol Med Chir (Tokyo) 49: 434-437, 2009

30. Tachibana S, Harada K, Abe T, Yamada H, Yokota A: Syringomyelia secondary to tonsillar herniation caused by posterior fossa tumors. Surg Neurol 43: 470-475, 1995

31. Takeuchi A, Miyamoto K, Sugiyama S, Saitou M, Hosoe $\mathrm{H}$, Shimizu KC: Spinal arachnoid cysts associated with syringomyelia: Report of two cases and a review of the literature. J Spinal Disord Tech 16(2): 207-211, 2003

32. Thakar S, Kiran NA, Hegde AS: A sacral arachnoid cyst causing holocord syringomyelia. J Neurosurg Pediatr 8(3): 299-302, 2011

33. Van Paesschen W, Van den Kerchove M, Appel B, Klaes R, Neetens I, Lowenthal A: Arachnoiditis ossificans with arachnoid cyst after cranial tuberculous meningitis. Neurology 40: 714-716, 1990

34. Wang MY, Levi AD, Green BA: Intradural spinal arachnoid cysts in adults. Surg Neurol 60(1): 49-55, 2003

35. Willems PW: An arachnoid cyst presenting as an intramedullary tumor. J Neurol Neurosurg Psychiatry 68:508-510,2000

36. Wu FZ, Fu JH, Chen JY, Lai PH: Teaching neurolmages: Acquired Chiari malformation with syringohydromyelia caused by posterior fossa tumor. Neurology 75: 59, 2010 